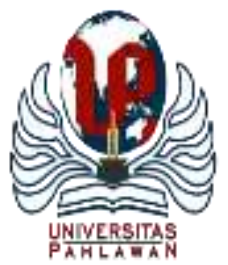

Edukatif : Jurnal Ilmu Pendidikan Volume 3 Nomor 6 Tahun 2021 Halm 4614 - 4627 EDUKATIF: JURNAL ILMU PENDIDIKAN

Research \& Learning in Education

https:/ledukatif.org/index.php/edukatif/index

\title{
Pengembangan Modul IPA SD Berbasis Model Research Based Learning (RBL) untuk Keterampilan 4C's Siswa Sekolah Dasar pada Pembelajaran Tematik
}

\author{
Nina Nurhasanah ${ }^{1 凶}$, Muhammad Subhan ${ }^{2}$, Estuhono $^{3}$ \\ Universitas Dharmas Indonesia, Indonesia ${ }^{1,2,3}$ \\ E-mail : ninanurhasanah2456@gmail.com ${ }^{1}$, subhanundhari07@ gmail.com ${ }^{2}$, estuhono023@ gmail.com ${ }^{3}$
}

\begin{abstract}
Abstrak
Di SDN 221/II Talang Pamesun dalam proses pembelajaran IPA siswa kurang berpikir kritis, kreatif dan kolaboratif, minimnya materi terdapat dalam buku siswa menyebabkan siswa kurang mendapat informasi yang lebih luas tentang materi IPA di kelas IV. Untuk mengatasinya peneliti berupaya mengembangkan bahan ajar berupa modul IPA bertujuan untuk membantu siswa mendapatkan wawasan baru mengenai pembelajaran IPA di kelas IV, menambah bahan ajar yang ada di sekolah dan menghasilkan pengembangan modul berbasis Research Based Learning (RBL) di kelas IV SD yang valid, praktis dan efektif sehingga dapat meningkatkan hasil belajar siswa di SDN 221/II Talang Pamesun. Jenis penelitian adalah penelitian pengembangan yaitu model pengembangan 4-D yaitu pendefinisian (define,) Perancangan (design), Pengembangan (develop) dan penyebaran (desseminate). Hasil penilaian validasi modul pembelajaran IPA pada penilaian validitas oleh tiga orang ahli mempunyai skor rata-rata $81 \%$ dengan kategori sangat valid. Pada penilaian praktikalitas mempunyai skor rata-rata 95\% dengan kategori sangat praktis. Hasil penilaian efektifitas modul pembelajaran IPA dengan skor rata-rata 78,57\% dikategorikan sangat efektif artinya modul dapat meningkatkan hasil belajar siswa. Modul pembelajaran berbasis model RBL untuk keterampilan 4C's dapat digunakan sebagai alternatif sumber belajar untuk menunjang proses pembelajaran sehingga dapat membangkitkan 4C's siswa.
\end{abstract}

Kata Kunci: Pengembangan, Modul IPA, RBL, $4 C$ 's

\begin{abstract}
At SDN 221/II Talang Pamesun in the science learning process students lack critical, creative and collaborative thinking, the lack of material contained in student books causes students to lack wider information about science material in grade IV. To overcome this, researchers are trying to develop teaching materials in the form of science modules aimed at helping students gain new insights about science learning in grade IV, adding teaching materials in schools and producing research-based learning (RBL)-based module development in grade IV SD that is valid, practical. and effective so that it can improve student learning outcomes at SDN 221/II Talang Pamesun. The type of research is development research, which is a 4-D development model, namely defining (define), Design (design), develop (develop) and disseminate (desseminate). The results of the validation assessment of the science learning module on the validity assessment by three experts had an average score of $81 \%$ with a very valid category. In the practicality assessment, it has an average score of $95 \%$ with a very practical category. The results of the assessment of the effectiveness of the science learning module with an average score of $78.57 \%$ are categorized as very effective, meaning that the module can improve student learning outcomes. The RBL model-based learning module for 4C's skills can be used as an alternative learning resource to support the learning process so that it can arouse students' $4 C^{\prime}$ 's.
\end{abstract}

Keywords: Development, Science Module, RBL, $4 C$ 's.

Copyright (c) 2021 Nina Nurhasanah, Muhammad Subhan, Estuhono

$\square$ Corresponding author

Email : ninanurhasanah2456@gmail.com

DOI : $\quad$ https://doi.org/10.31004/edukatif.v3i6.1530

ISSN 2656-8063 (Media Cetak)

ISSN 2656-8071 (Media Online)

Edukatif : Jurnal Ilmu Pendidikan Vol 3 No 6 Tahun 2021 p-ISSN 2656-8063 e-ISSN 2656-8071 
4615 Pengembangan Modul IPA SD Berbasis Model Research Based Learning (RBL) untuk Keterampilan 4C's Siswa Sekolah Dasar pada Pembelajaran Tematik - Nina Nurhasanah, Muhammad Subhan, Estuhono DOI: https://doi.org/10.31004/edukatif.v3i6.1530

\section{PENDAHULUAN}

Pendidikan adalah hal pokok dalam kemajuan suatu bangsa, tanpa pendidikan suatu negara akan jauh tertinggal oleh negara lain. Pendidikan merupakan usaha sadar dan terencana dalam proses pembelajaran supaya siswa dapat mengerti, paham dan membuat siswa lebih kritis dalam berpikir. Menurut UU Nomor 20 tahun 2003 pada pasal 3 tujuan pendidikan yaitu mewujudkan suasana belajar dan proses pembelajaran agar siswa secara aktif mengembangkan potensi dalam dirinya untuk menjadi manusia yang beriman dan bertakwa kepada Tuhan Yang Maha Esa, berakhlak mulia, sehat, berilmu, cakap, kreatif, mandiri dan menjadi warga negara yang demokratis serta bertanggung jawab.

Pada saat ini kurikulum yang ada di Indonesia menghadapi perbaikan, pertama kurikulum 2006 yang sering disebut dengan Kurikulum Tingkat Satuan Pendidikan (KTSP) saat ini disempurnakan menjadi kurikulum 2013. Kurikulum 2013 dipersiapkan dengan mengelaborasikan keselarasan antara tingkah laku psikis ataupun kemasyarakatan, keterampilan intelektual maupun kemampuan yang dilakukan dalam sistem pembelajaran. Pada kurikulum 2013 kompetensi inti maupun kompetensi dasar sudah ditentukan oleh pemerintah, langkah untuk menggapainya dan bahan ajar yang dipakai diberikan seutuhnya pada pendidik sebagai tenaga kerja yang berpengalaman untuk membuatnya (Usmeldi, 2016).

Pembelajaran dalam keterampilan abad 21, pendidik perlu memberi dorongan kepada peserta didik untuk ikut serta dalam proses pembelajaran secara teratur. Keterampilan abad 21 sering dikatakan dengan 4C yaitu keterampilan yang dapat dikuasai oleh peserta didik sebagai modal di abad 21 saat ini. Keterampilan abad 21 mampu mengembangkan serta memajukan kerjasama pada sebuah kelompok dalam menyelesaikan suatu masalah, menumbuhkan rasa toleransi atas perselisihan argumen teman, berusaha untuk berpikir kritis maupun kreatif dalam memecahkan suatu masalah tentang menghubungkan sesuatu (Septikasari \& Frasandy, 2018). Pembelajaran IPA di Sekolah Dasar merupakan pondasi awal dalam menciptakan siswa-siswa yang memiliki pengetahuan, keterampilan dan sikap ilmiah (Tursinawati, 2013). IPA merupakan konsep pembelajaran yang alamiah dan memiliki hubungan yang sangat luas dengan kehidupan manusia (Surahman et al., 2017). Selanjutnya, IPA merupakan mata pelajaran sains yang menjelaskan berbagai gejala fisik fenomena yang terjadi di alam, baik secara teoritis maupun matematis (Estuhono, 2020). Jadi IPA merupakan konsep pembelajaran yang alamiah dan berhubungan dengan kehidupan manusia, serta pembelajaran IPA dapat menciptakan siswa-siswa yang memiliki pengetahuan, keterampilan dan sikap ilmiah. Salah satu model pembelajaran yang dapat mendorong peserta didik agar dapat berpikir secara kritis, berkomunikasi dengan baik, saling bekerja sama (collaboration) dan mampu mendapatkan sesuatu yang baru (creativity) yakni dengan menggunakan model research based learning.

Pembelajaran IPA dapat dioptimalkan dengan keterampilan belajar dan berinovasi 4C's (Meilani et al., 2020). 4C's terdiri dari keterampilan berpikir berpikir kritis dan pemecahan masalah (critical thinking and problem solving), berkomunikasi (communication), berkolaborasi (collaboration) dan kreativitas (creativity). Keterampilan 4C's diatas harus dimiliki siswa dari semua jenjang pendidikan, khususnya pada jenjang Pendidikan dasar. Sehingga pembelajaran IPA yang menggunakan keterampilan 4C's dapat meningkatkan hasil belajar peserta didik (Meilani et al., 2020).

Berdasarkan observasi yang dilakukan peneliti di SD 221/II Talang Pamesun peneliti menemukan beberapa permasalahan diantaranya, pertama siswa lambat dalam menjawab soal Latihan pada LKS, dikarenakan kurangnya materi yang dapat dibaca siswa sebagai acuan dalam menjawab pertanyaan Latihan. Pada materi pelajaran IPA siswa tidak menunjukkan proses berpikir kritis, kreatif dan kerjasamanya dalam pembelajaran. Kemudian siswa masih canggung bertanya kepada guru jika ada yang belum dipahami siswa dalam proses pembelajaran. Bahan ajar IPA yang digunakan saat peneliti melakukan PLP di SD 221/II Talang Pamesun adalah buku paket tematik Terpadu Kurikulum 2013 dan LKS (Lembar Kerja Siswa). Minimnya 
4616 Pengembangan Modul IPA SD Berbasis Model Research Based Learning (RBL) untuk Keterampilan 4C's Siswa Sekolah Dasar pada Pembelajaran Tematik - Nina Nurhasanah, Muhammad Subhan, Estuhono

DOI: https://doi.org/10.31004/edukatif.v3i6.1530

materi yang terdapat dalam buku siswa yang menyebabkan siswa kurang mendapat informasi yang lebih luas tentang pelajaran IPA.

Berdasarkan permasalahan diatas, peneliti berupaya mengembangkan bahan ajar berupa modul dengan tujuan untuk membantu siswa mendapatkan wawasan baru mengenai pembelajaran IPA dan menambah bahan ajar yang ada di sekolah tersebut.

Modul yang ingin dikembangkan berupaya untuk menjadikan siswa sebagai pusat dalam pembelajaran dan guru sebagai fasilitator. Modul yang dikembangkan berupaya memberikan materi yang sangat jelas, Menggunakan gambar-gambar yang unik dan menggunakan warna yang menarik sehingga siswa dapat dengan mudah memahami isi modul yang kembangkan. Modul ini menggunakan model Research Based Learning (RBL) yang dalam proses penerapannya dapat meningkatkan aktifitas siswa dalam proses belajar. Model research based learning yaitu salah satu metode student centered learning yang menyatukan riset di dalam tahap pembelajaran (Estuhono, Festiyed dan Bentri, A. 2019). Oleh karena itu, dengan hal tersebut untuk mempersiapkan peserta didik yang mempunyai keterampilan 4C (Creativity and Innovation, Collaboration, Communication, Critical Thinking and Problem Solving,) dibutuhkan sebuah bahan ajar yang cocok, yakni dengan memakai modul.

Salah satu upaya untuk menekankan keterampilan 4C adalah menggunakan bahan ajar seperti modul. Modul merupakan bahan ajar yang bersifat mandiri, sehingga peserta didik dituntut untuk secara mandiri tanpa adanya bimbingan guru secara langsung. Keberadaan modul sangat diperlukan untuk menunjang keberhasilan tujuan pembelajaran yang diharapkan karena mampu memberikan informasi dan membantu kegiatan belajar peserta didik agar lebih terarah. Berdasarkan permasalahan yang ditemukan oleh peneliti, maka rumusan masalah dalam penelitian ini adalah bagaimana mengembangkan modul IPA berbasis model research based learning pada keterampilan 4C's siswa pokok bahasan tema 3 peduli terhadap makhluk hidup tentang tumbuhan hijau yang valid, praktis dan efektif?.

\section{METODE PENELITIAN}

Penelitian yang digunakan peneliti adalah jenis penelitian pengembangan (Research and Development), karena peneliti akan mengembangan produk bahan ajar berupa modul IPA materi tumbuhan hijau berbasis research based learning untuk keterampilan 4C's siswa.

Menurut Borg and Gall (1998) dalam Ainin (2013) berpendapat bahwa metode penelitian pengembangan merupakan suatu metode riset yang tujuannya untuk mengembangkan dan memvalidasi produk tertentu. Untuk menghasilkan produk tertentu digunakan penelitian bersifat analisis kurikulum dan analisis materi serta untuk mengkaji keefektifan produk agar bisa dipakai di sekolah. Data yang diambil oleh peneliti yaitu data kualitatif dan kuantitatif. Data kualitatif dan kuantitatif adalah data yang diambil dari hasil validasi yang dilakukan oleh validator, data praktikalitas diambil melalui angket respon guru serta data efektivitas yang diambil melalui penyebaran angket respon siswa dan tes soal terhadap modul IPA berbasis model research based learning pada keterampilan 4C siswa.

Dalam pengembangan modul ini menggunakan model 4-D (Define, Design, Development and Desseminate).

\section{Pendefinisian (define)}

Tahap ini melakukan kegiatan analisis kurikulum dan analisis materi serta analisis karakteristik siswa serta model penelitian dan pengembangan yang cocok digunakan untuk mengembangkan produk. Dilihat dari kondisi SDN 08 Sitiung bahwa di SDN 221/II Talang Pamesun dalam proses pembelajaran IPA siswa kurang berpikir kritis, kreatif dan kolaboratif, minimnya materi terdapat dalam buku siswa menyebabkan siswa kurang mendapat informasi yang lebih luas tentang materi IPA di kelas IV, sehingga 
4617 Pengembangan Modul IPA SD Berbasis Model Research Based Learning (RBL) untuk Keterampilan 4C's Siswa Sekolah Dasar pada Pembelajaran Tematik - Nina Nurhasanah, Muhammad Subhan, Estuhono DOI: https://doi.org/10.31004/edukatif.v3i6.1530

bahan ajar belum menekankan keterampilan 4C's siswa, maka keterampilan 4C's siswa belum menjadi perhatian dan belum menerapkannya pada setiap mata pelajaran yang ada, sehingga keterampilan 4C's siswa belum tercapai. Oleh karena itu, dari permasalahan tersebut di perlukan adanya bahan ajar berbentuk modul berbasis model research based learning pada keterampilan 4C's siswa.

2. Perancangan (design)

Tahap ini melakukan perancangan (design) sebuah produk berupa modul, penyusunan instrumen validitas, instrumen praktikalitas dan instrumen efektivitas.

a. Instrumen Validitas

Matondang (2009) menjelaskan tentang instrumen validitas berikut ini: validitas berasal dari kata validity yang mempunyai arti sejauh mana ketepatan dan kecermatan suatu instrumen, suatu tes dikatakan memiliki validitas yang tinggi apabila alat tersebut menjalankan fungsi ukur secara tepat atau memberikan hasil ukur yang sesuai. Artinya hasil pengukuran dari pengukur tersebut merupakan besaran yang secara akurat mencerminkan fakta atau kondisi sebenarnya dari apa yang diukur.

Jadi instrumen validitas merupakan ketepatan dan kecermatan suatu alat ukur dalam melakukan fungsinya, jika suatu instrumen dikatakan valid karna memiliki tingkat validitas yang tinggi.

Analisis data validitas dilakukan dengan menggunakan skala likert 1-4 dengan skor 1 jika Tidak Setuju (TS), skor 2 jika Kurang Setuju (KS), skor 3 jika Setuju (S), skor 4 jika Sangat Setuju (SS). Dari skor yang diperoleh di hitung nilai validitasnya dengan menggunakan persamaan berikut:

$$
V=\frac{f}{n} \times 100 \%
$$

Dimana $\mathrm{V}$ merupakan nilai validitas, $\mathrm{f}$ merupakan skor yang diperoleh, $\mathrm{n}$ merupakan skor maksimum. Kategori validitas bahan ajar berdasarkan nilai akhir yang diperoleh dalam skala (0-100) bisa dilihat pada Tabel berikut:

Tabel 1. Kategori Validitas

\begin{tabular}{cc}
\hline Interval & Kategori \\
\hline $0 \leq \mathrm{V} \leq 20$ & Sangat tidak valid \\
\hline $21 \leq \mathrm{V} \leq 40$ & Tidak valid \\
\hline $41 \leq \mathrm{V} \leq 60$ & Kurang valid \\
\hline $61 \leq \mathrm{V} \leq 80$ & Valid \\
\hline $81 \leq \mathrm{V} \leq 100$ & Sangat valid \\
\hline \multicolumn{2}{c}{ (Dimodifikasi dari Riduwan, 2013) dalam (Aziz \& Prasetya, 2018) }
\end{tabular}

b. Instrumen Praktikalitas

Agustyaningrum \& Gusmania (2017) menjelaskan tentang instrumen praktikalitas berikut ini: instrumen praktikalitas merupakan tingkat keterpakaian atau kemudahan bahan ajar untuk digunakan oleh peserta didik. Aspek praktikalitas yang diukur adalah aspek kemudahan penggunaan dan aspek penyajian. Untuk aspek kemudahan penggunaan meliputi kemudahan memahami materi dan bahasa yang digunakan dalam modul. Sedangkan aspek penyajian fokus pada tampilan modul. Harisman (2016) menjelaskan tentang instrumen praktikalitas berikut ini: praktikalitas merupakan tingkat keterpakaian Modul oleh peserta didik, dengan melakukan uji coba menggunakan Modul yang telah direvisi. Praktikalitas merupakan tingkat keterpakaian Modul oleh peserta didik, dengan melakukan uji coba menggunakan Modul yang telah direvisi materi yang disajikan, mudah pemeriksaannya serta lengkap dengan petunjuk yang jelas. Jika hasil belum praktis, dilakukan perbaikan dan hasil perbaikan harus divalidasi terlebih dahulu. Setelah hasil perbaikan dinyatakan valid, dilakukan uji praktikalitas terhadap perbaikan. Ini dilakukan sampai ditemukan Modul yang praktis. 
Jadi, kesimpulannya instrumen praktikalitas merupakan tingkat keterpakaian atau kemudahan modul oleh peserta didik yang diukur adalah kemudahan memahami materi dari bahasa yang digunakan dalam modul dan fokus pada tampilan modul.

Analisis praktikalitas diperoleh dari hasil penilaian yang akan dilakukan oleh guru dan peserta didik kelas IV SDN 08 Sitiung. Analisis data praktikalitas dilakukan dengan menggunakan skala likert 1-4 dengan skor 1 jika Tidak Setuju (TS), skor 2 jika Kurang Setuju (KS), skor 3 jika Setuju (S), skor 4 jika Sangat Setuju (SS). Dari skor yang diperoleh di hitung nilai validitasnya dengan menggunakan persamaan berikut:

$$
P=\frac{f}{n} \times 100 \%
$$

Dimana $\mathrm{P}$ merupakan nilai praktikalitas, $\mathrm{f}$ merupakan skor yang diperoleh, $\mathrm{n}$ merupakan skor maksimum. Kategori validitas bahan ajar berdasarkan nilai akhir yang diperoleh dalam skala (0-100) bisa dilihat pada Tabel berikut:

Tabel 2. Kategori Praktikalitas

\begin{tabular}{cc}
\hline Interval & Kategori \\
\hline $0 \leq \mathrm{P} \leq 20$ & Sangat tidak valid \\
\hline $21 \leq \mathrm{P} \leq 40$ & Tidak valid \\
\hline $41 \leq \mathrm{P} \leq 60$ & Kurang valid \\
\hline $61 \leq \mathrm{P} \leq 80$ & Valid \\
\hline $81 \leq \mathrm{P} \leq 100$ & Sangat valid \\
\hline
\end{tabular}

(Dimodifikasi dari Riduwan, 2013) dalam (Aziz \& Prasetya, 2018)

\section{c. Instrumen Efektivitas}

Wati (2018) menjelaskan tentang instrumen efektivitas yang berarti efektif dapat membuahkan hasil, mulai berlaku, ada pengaruh/akibat/efeknyaEfektivitas adalah suatu ukuran yang menyatakan seberapa jauh target (kuantitas, kualitas dan waktu) telah tercapai. Laili et al (2019) menjelaskan bahwa efektivitas yaitu sebagai dampak atau hasil yang timbul dari suatu tindakan, dalam hal ini dampak pada penggunaan modul terhadap hasil belajar. Uji efektivitas dilakukan sebagai ukuran tingkat keberhasilan dari suatu proses pembelajaran. Modul dapat dikatakan efektif apabila memberikan dampak yang baik terhadap hasil belajar peserta didik. Hasil uji efektivitas diperoleh dari hasil ujian posttest dengan mengerjakan soal objektif yang sudah divalidasi sebelumnya. Hasil efektivitas juga diperoleh berdasarkan hasil penilaian praktek dan tugas proyek yang dikerjakan sisawa. Analisis efektivitas modul dilihat dari ketuntasan klasikal yang diperoleh dengan membandingkan hasil post-test dengan nilai KKM yang ditetapkan sekolah. Bila ketuntasan klasikal peserta didik telah tercapai maka modul pembelajaran dikategorikan efektif.

Jadi kesimpulannya, efektivitas merupakan hasil yang timbul dari suatu tindakan, dalam hal ini dampak pada penggunaan modul terhadap hasil belajar peserta didik. Keberhasilan suatu produk dikatakan efektif apabila ketuntasan klasikal peserta didik telah tercapai.

Keefektifan modul dapat diketahui dengan menganalisis data tes hasil belajar siswa. Penskoran untuk masing - masing tes belajar di analisis dalam skala 0-100, diharapkan siswa bisa mencapai Kriteria Ketuntasan Minimal (KKM) yang sudah ditetapkan yaitu 70. Persentase menggunakan persamaan:

$$
E=\frac{f}{n} \times 100 \%
$$


4619 Pengembangan Modul IPA SD Berbasis Model Research Based Learning (RBL) untuk Keterampilan 4C's Siswa Sekolah Dasar pada Pembelajaran Tematik - Nina Nurhasanah, Muhammad Subhan, Estuhono DOI: https://doi.org/10.31004/edukatif.v3i6.1530

Dimana E merupakan nilai efektivitas, f merupakan skor yang diperoleh, $\mathrm{n}$ merupakan skor maksimum. Kategori validitas bahan ajar berdasarkan nilai akhir yang diperoleh dalam skala (0-100) bisa dilihat pada Tabel berikut:

Tabel 3. Kategori Efektivitas

\begin{tabular}{|c|c|}
\hline Interval & Kategori \\
\hline $0 \leq \mathrm{P} \leq 20$ & Sangat tidak valid \\
\hline $21 \leq \mathrm{P} \leq 40$ & Tidak valid \\
\hline $41 \leq \mathrm{P} \leq 60$ & Kurang valid \\
\hline $61 \leq \mathrm{P} \leq 80$ & Valid \\
\hline $81 \leq \mathrm{P} \leq 100$ & Sangat valid \\
\hline
\end{tabular}

(Dimodifikasi dari Riduwan, 2013) dalam (Aziz \& Prasetya, 2018)

3. Pengembangan (development)

Tahap ini bertujuan untuk menerjemahkan spesifikasi perancangan perangkat pembelajaran IPA materi tumbuhan hijau model RBL untuk keterampilan 4C's kedalam bentuk fisik atau wujud nyata produk. Sehingga dalam kegiatan ini menghasilkan bentuk produk pengembangan yaitu bahan ajar IPA materi tumbuhan hijau berbasis model RBL untuk keterampilan 4C's yang masih perlu di uji kevalidannya. Kemudian bentuk bahan ajar di evaluasi oleh validator untuk mengetahui tingkat validnya, apabila belum memenuhi kriteria valid maka dilakukan perbaikan.

4. Penyebaran (desseminate)

Tahap ini dibagi menjadi tiga kegiatan, yaitu: validation testing, packaging, diffusion, and adoption. Pada tahap validation testing (pengujian validasi), produk yang sudah direvisi pada tahap pengembangan kemudian diimplementasikan dilakukan pengukuran ketercapaian tujuan. Pengukuran ini dilakukan untuk mengetahui efektivitas produk yang dikembangkan. Setelah produk diimplementasikan, peneliti perlu melihat hasil pencapaian tujuan. Kegiatan terakhir dari tahap pengembangan adalah melakukan packaging (pengemasan), diffusion and adoption. Pengemasan model pembelajaran dapat dilakukan dengan mencetak buku panduan penerapan model pembelajaran. Setelah buku dicetak, buku tersebut disebarluaskan supaya dapat diserap (difusi) atau dipahami orang lain dan digunakan (diadopsi) pada kelas mereka.

\section{HASIL DAN PEMBAHASAN PENELITIAN}

Penelitian pengembangan ini menghasilkan sebuah produk berupa modul IPA berbasis model Research Based Learning (RBL) pada tema peduli terhadap makhluk hidup. Modul berbasis RBL dalam penelitian ini dikembangkan melalui beberapa tahap sesuai dengan prosedur dari pengembangan 4D yaitu define (Pendefinisian), Design (Perancangan), Develop (Pengembangan), dan Desseminate (Penyebaran). Adapun aplikasi 4D dalam pengembangan produk ini sebagai berikut:

\section{Hasil Tahap Penelitian atau define}

Tahap pendefinisian terdiri dari 4 aspek yang terdiri dari analisis kurikulum, analisis karakteristik siswa, dan analisis materi. Adapun hasil analisis tersebut dapat diuraikan sebagai berikut:

a.) Hasil analisis kurikulum dan Analisis Materi IPA

Edukatif : Jurnal Ilmu Pendidikan Vol 3 No 6 Tahun 2021 p-ISSN 2656-8063 e-ISSN 2656-8071 
4620 Pengembangan Modul IPA SD Berbasis Model Research Based Learning (RBL) untuk Keterampilan 4C's Siswa Sekolah Dasar pada Pembelajaran Tematik - Nina Nurhasanah, Muhammad Subhan, Estuhono DOI: https://doi.org/10.31004/edukatif.v3i6.1530

Tahap ini dilakukan dengan mengkaji terhadap kurikulum 2013 pada tema 3 peduli terhadap makhluk hidup kelas IV SD. Analisis kurikulum diperlukan untuk mempelajari cakupan materi, tujuan pembelajaran, pemilihan strategi yang sesuai dengan landasan untuk mengembangkan modul IPA. Analisis kurikulum yang difokuskan pada analisis Kompetensi Dasar pada pembelajaran IPA materi cahaya sesuai dengan kurikulum 2013. Berdasarkan analisis indicator yang digunakan di sekolah yang dilakukan oleh peneliti saat studi pendahuluan, peneliti mendapatkan bahwa indikator yang dirumuskan belum mewakili KD yang harus dikuasai siswa, selain itu penyusunan indikator dan tujuan pembelajaran belum sesuai dengan keterampilan yang akan dicapai.

Maka dibutuhkan modul yang menarik sehingga siswa antusias dan mampu memahami materi tersebut. Untuk mengembangkan materi tersebut dipadukan dengan langkah-langkah yang ada pada model RBL, karena model ini dapat membantu siswa mampu berpikir kritis, komunikasi yang baik, kolaborasi dengan kelompoknya dan kreativitas yang semakin berkembang atau biasa disebut keterampilan 4C's.

b.) Hasil analisis karakteristik Siswa

Pada tahap ini peneliti melaksanakan studi pendahuluan dengan melakukan PLP yang dilakukan pada bulan agustus yang berhubungan dengan pembelajaran IPA kelas IV di sekolah dasar 221/II Talang Pamesun di peroleh informasi bahwa terdapat kendala dalam proses pembelajaran IPA. Hasil wawancara yang dilakukan dengan wali kelas IV disimpulkan bawah kurangnya aktivitas siswa dalam pembelajaran dikarena siswa tidak aktif dalam menjawab pertanyaan yang diberikan oleh guru dalam proses pembelajaran. Keadaan dikelas yang selalu terasa jenuh ketika guru menyampaikan materi sehingga siswa lebih memilih berbicara dengan temannya atau bermain sendiri. Model pembelajaran yang digunakan oleh guru dalam pembelajaran belum bervariasi. Sehingga hasil belajar siswa cenderung masih rendah pada pembelajaran IPA. Artinya guru belum menggunakan keterampilan 4C's di dalam bahan ajar yang digunakan. Selain itu siswa kurang mampu dalam bekerja sama atau berdiskusi secara kelompok.

\section{Hasil Tahapan Perancangan atau design}

Pada tahap ini peneliti melakukan perancanaan instrumen penilain kelayakan bahan ajar modul dan merancang bahan ajar modul pembelajaran untuk siswa kelas IV sekolah dasar berdasarkan materi yang terdapat dalam pembelajaran dalam tema 3 peduli terhadap makhluk hidup dan subtema 1 hewan dan tumbuhan di lingkungan rumahku serta memperhatikan krakteristik siswa. Sebelum di lakukannya tahap penyusunan instrumen penilain bahan ajar modul, terlebih dahulu di laksanakan rancangan desain pada bahan ajar modul pembelajaran tersebut. Adapun desain bahan ajar modul ini meliputi:

a. Hasil rancangan bahan ajar modul IPA

Penyajian modul ini disusun secara urut yang terdiri dari halaman sampul atau cover, kata pengantar. Adapun komponen - komponen tersebut akan dibahas lebih rinci dapat dilihat pada gambar sebagai berikut:

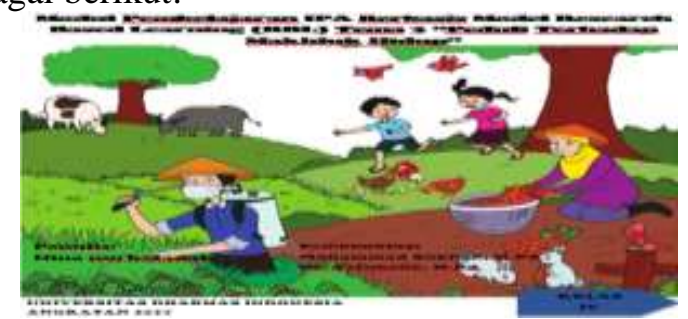

Gambar 1 Desain Cover Pada

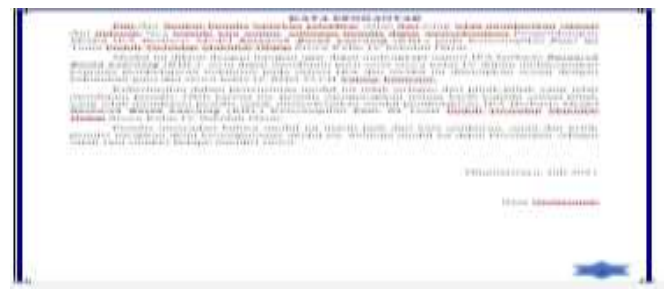

Gambar 2 Kata Pengantar Pada Modul

Halaman Depan Modul IPA

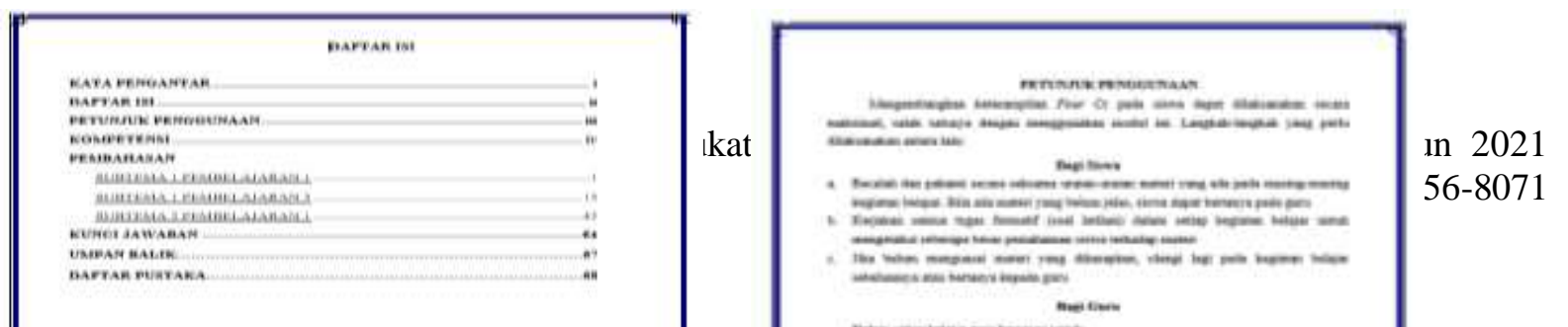


4621 Pengembangan Modul IPA SD Berbasis Model Research Based Learning (RBL) untuk Keterampilan 4C's Siswa Sekolah Dasar pada Pembelajaran Tematik - Nina Nurhasanah, Muhammad Subhan, Estuhono DOI: https://doi.org/10.31004/edukatif.v3i6.1530

Gambar 3 Daftar Isi Pada Modul

Gambar 4 Petunjuk Pada Modul

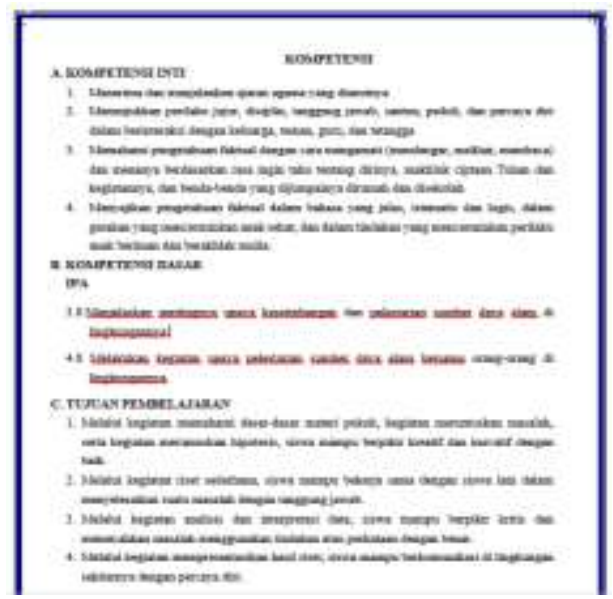

Gambar 5 KI, KD, Indikator dan Tujuan Pembelajaran
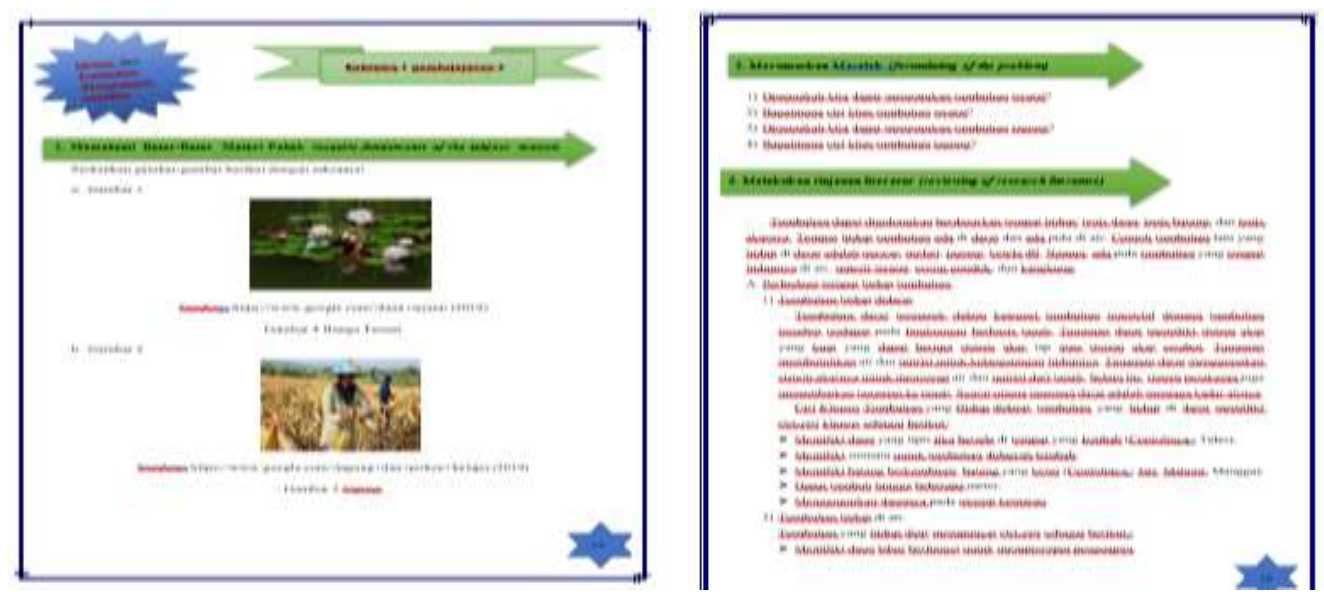

Gambar 6 Informasi Pendukung atau Materi

Edukatif : Jurnal Ilmu F

$\mathrm{p}-\mathrm{I}$ :

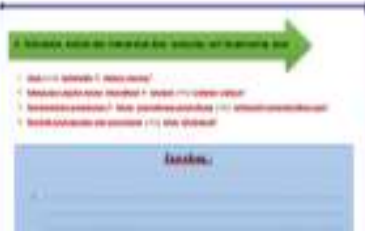


4622 Pengembangan Modul IPA SD Berbasis Model Research Based Learning (RBL) untuk Keterampilan 4C's Siswa Sekolah Dasar pada Pembelajaran Tematik - Nina Nurhasanah, Muhammad Subhan, Estuhono DOI: https://doi.org/10.31004/edukatif.v3i6.1530
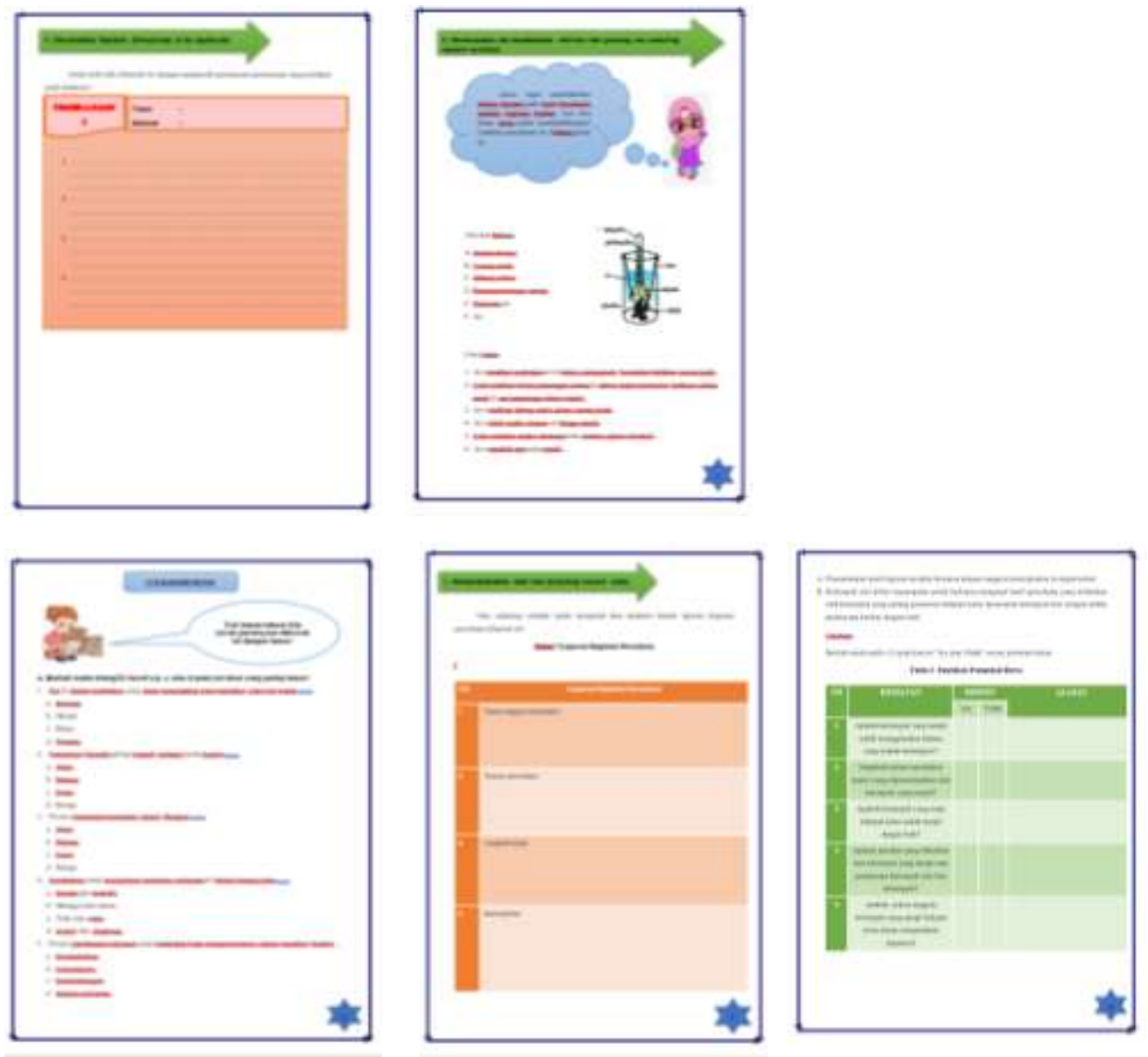

Gambar 4 Latihan dan tugas tugas

\section{Lembar Validasi}

Pada lembar validasi di isi oleh tiga ahli validator. Adapun hasil validasi isi oleh validator Moh. Rosyid Mahmudi, M.Si dengan hasil $75 \%$ di kategorikan valid, hasil validasi konstruk oleh validator Dr. Raimon Efendi, M.Kom dengan hasil 96\% dikategorikan Sangat Valid, dan hasil validasi bahasa oleh validator Aprimadedi, M.Pd dengan hasil 71\% dikategorikan valid.

\section{Lembar Praktikalitas}

Hasil rancangan lembar praktikalitas terdapat petunjuk pengisian dan aspek penilaian yang akan dinilai oleh guru kelas IV. Hasil praktikalitas oleh praktisi Guru Kelas IV dengan hasil 95\% dikategorikan sangat praktis.

\section{Lembar Efektifitas}

Hasil rancangan validasi lembar efektifitas (tes hasil belajar) efektifitas dengan hasil belajar siswa ketuntasan hasil belajar siswa dengan rata-rata $78 \%$ dikategorikan sangat efektif. Sedangkan ketidak tuntasan siswa dengan rata-rata $21 \%$ dikategorikan tidak efektif. 
4623 Pengembangan Modul IPA SD Berbasis Model Research Based Learning (RBL) untuk Keterampilan 4C's Siswa Sekolah Dasar pada Pembelajaran Tematik - Nina Nurhasanah, Muhammad Subhan, Estuhono DOI: https://doi.org/10.31004/edukatif.v3i6.1530

\section{Hasil Tahapan Pengembangan atau development}

\section{1.) Validasi Ahli}

Penyajian data validitas pada uji coba produk modul IPA kelas IV sekolah dasar berguna untuk mengetahui kelayakan dan ketepatan modul IPA yang telah dibuat oleh peneliti.

Tabel 4 Validasi Modul IPA

\begin{tabular}{|c|c|c|c|c|}
\hline $\mathrm{NO}$ & Validator & Hasil $\mathrm{v}=\frac{f}{n} \times 100 \%$ & Kategori & Keterangan \\
\hline 1 & $\begin{array}{l}\text { Moh. Rosyid } \\
\text { Mahmudi, M.Si }\end{array}$ & $\begin{array}{l}\mathrm{v}=\frac{27}{36} \times 100 \% \\
\mathrm{v}=75 \%\end{array}$ & Valid & \multirow{3}{*}{$\begin{array}{l}\text { Dosen FKIP } \\
\text { UNDHARI }\end{array}$} \\
\hline 2 & $\begin{array}{l}\text { Dr. Raimon Efendi, } \\
\text { M.Kom }\end{array}$ & $\begin{array}{l}\mathrm{v}=\frac{27}{28} \times 100 \% \\
\mathrm{v}=96 \%\end{array}$ & $\begin{array}{l}\text { Sangat } \\
\text { Valid }\end{array}$ & \\
\hline 3 & Aprimadedi, M.Pd & $\begin{array}{l}\mathrm{v}=\frac{20}{28} \times 100 \% \\
\mathrm{v}=71 \%\end{array}$ & Valid & \\
\hline & Jumlah keseluruhan & $\begin{array}{l}242 / 3 \times 100 \% \\
=81 \%\end{array}$ & $\begin{array}{l}\text { Sangat } \\
\text { Valid }\end{array}$ & \\
\hline
\end{tabular}

Dari tabel 4, dapat dilihat bahwa hasil validitas yang dilakukan oleh ketiga validator memberikan hasil rata - rata nilai 81\% (Sangat Valid) sehingga modul bisa diterapkan di Sekolah Dasar.

2.) Revisi Produk

Berikut ini adalah nama validator serta sarannya, dapat dilihat pada tabel berikut:

Tabel 5 Nama dan Saran Dari Validator

\begin{tabular}{ll}
\hline \multicolumn{1}{c}{ Validator } & \multicolumn{1}{c}{ Komentar dan Saran } \\
\hline $\begin{array}{l}\text { Moh. Rosyid Mahmudi, } \\
\text { M.Si }\end{array}$ & $\begin{array}{l}\text { Cek perbaiki jika ada tulisan yang } \\
\text { tidak sesuai dengan EYD }\end{array}$ \\
\hline Dr. Raimon Efendi, M.Kom & $\begin{array}{l}\text { Modul sudah layak untuk diuji cobakan } \\
\text { di penelitian }\end{array}$ \\
\hline Aprimadedi, M.Pd & Perbaiki ejaan \\
\hline
\end{tabular}

a. Uji Coba

Penelitian ini dilakukan di kelas IV sekolah dasar 221/II Talang Pamesun, dengan jumlah siswa 14 orang, Penyajian data uji coba produk modul IPA untuk mengetahui kepraktisan dan keefektifan, dapat dilihat dari tabel berikut:

Tabel 6 Data Praktikalitas Modul Pembelajaran IPA

\begin{tabular}{lcccl}
\hline No & Nama Guru & Hasil $\mathrm{p}=\frac{f}{n} \times 100 \%$ & \multicolumn{1}{c}{ Kategori } & \multicolumn{1}{c}{ Keterangan } \\
\hline 1. & Hartini S.Pd & $p=\frac{38}{40} \times 100 \%$ & Sangat Praktis & Wali Kelas IV \\
& & & SDN 221 Talang \\
& & & Pamesun \\
\hline
\end{tabular}


4624 Pengembangan Modul IPA SD Berbasis Model Research Based Learning (RBL) untuk Keterampilan 4C's Siswa Sekolah Dasar pada Pembelajaran Tematik - Nina Nurhasanah, Muhammad Subhan, Estuhono DOI: https://doi.org/10.31004/edukatif.v3i6.1530

Berdasarkan analisis data penilaian kepraktisan oleh praktisi memperoleh hasil 100\% dengan kategori sangat praktis.

Tabel 7 Data Uji Coba Modul Pembelajaran IPA

\begin{tabular}{llcc}
\hline No & Kriteria & Jumlah & Presentase \\
\hline 1. & Tuntas & $\mathbf{1 1}$ & $\mathbf{7 8 , 5 7 \%}$ \\
\hline 2. & Tidak Tuntas & $\mathbf{3}$ & $\mathbf{2 1 , 4 2 \%}$ \\
\hline
\end{tabular}

b. Analisis Akhir

Setelah melakukan analisis validasi ahli, praktis, dan efektifitas. Maka terdapatlah analisis akhir sebagai berikut:

1. Validasi ahli

Berdasarkan hasil penilaian validasi modul IPA yang telah dirancang peneliti mendapat rata-rata $81 \%$ dikategorikan sangat valid. Jadi hasil akhirnya modul IPA bisa diterapkan di Sekolah Dasar.

2. Uji Coba Praktikalitas

Berdasarkan hasil penilaian angket praktisi guru kelas IV modul IPA yang telah dirancang peneliti mendapat rata-rata $95 \%$ dikategorikan sangat praktis. Jadi hasil akhirnya modul IPA bisa membantu guru dalam proses belajar dan modul IPA bisa diterapkan di Sekolah Dasar.

\section{Uji Coba Efektifitas}

Berdasarkan uji coba soal kepada siswa peneliti mendapatkan hasil penilaian, Ketuntasan hasil belajar siswa dengan rata-rata $78,57 \%$ dikategorikan sangat efektif. Sedangkan ketidak tuntasan hasil belajar siswa dengan rata-rata $21,42 \%$ di kategorikan tidak efektif. Jadi hasil akhirnya modul IPA sangat efektif untuk membantu proses belajar siswa di sekolah maupun di rumah.

\section{c. Desseminate (Penyebaran)}

Tahap disseminate merupakan tahap penyebar luasan dan merupakan tahap akhir dari tahap penelitian dan pengembangan ini. Pada tahap ini penyebaran di lakukan di sekolah dasar 221/II Talang Pamesun dengan cara memberi modul IPA melalui wali kelas IV.

\section{Pembahasan}

Berdasarkan data yang didapat dari pegembangan modul IPA kelas IV. Maka didapatkan dengan kategori sangat valid, sangat praktis, dan sangat efektif.

\section{Validitas Modul IPA}

Hasil dasi validasi modul IPA kelas IV ini di isi oleh tiga validator yaitu dosen FKIP dan FILKOM UNDHARI. Validator adalah yang menvalidasi modul IPA yang terdiri dari tiga aspek yang dinilai, diantaranya adalah aspek isi atau materi, aspek konstruksi atau komponen penyajian serta aspek bahasa, dari tiga sapek tersebut mencakup 21 pertanyaan. Berdasarkan hasil dari ke 3 validator modul IPA didapatkan dengan jumlah persentase $81 \%$ yaitu dikategorikan sangat valid.

Matondang (2009) menjelaskan tentang instrumen validitas berikut ini: validitas berasal dari kata validity yang mempunyai arti sejauh mana ketepatan dan kecermatan suatu instrumen, suatu tes dikatakan memiliki validitas yang tinggi apabila alat tersebut menjalankan fungsi ukur secara tepat atau memberikan hasil ukur yang sesuai. Artinya hasil pengukuran dari pengukur tersebut merupakan besaran yang secara akurat mencerminkan fakta atau kondisi sebenarnya dari apa yang diukur. 
4625 Pengembangan Modul IPA SD Berbasis Model Research Based Learning (RBL) untuk Keterampilan 4C's Siswa Sekolah Dasar pada Pembelajaran Tematik - Nina Nurhasanah, Muhammad Subhan, Estuhono DOI: https://doi.org/10.31004/edukatif.v3i6.1530

Candra \& Indriyani (2014) menjelaskan tentang instrumen validitas berikut ini: validitas adalah pengukuran yang menunjukkan tingkat ketepatan (kesahihan) ukuran suatu instrumen terhadap konsep yang diteliti. Suatu instrumen adalah tepat untuk digunakan sebagai ukuran suatu konsep apabila memiliki tingkat validitas yang tinggi, dan sebaliknya apabila validitas rendah mencerminkan bahwa instrumen kurang tepat untuk diterapkan.

Maka dapat disimpulkan modul IPA sesuai kegunaan dan kebutuhan siswa kelas IV sekolah dasar 221/II Talang Pamesun. Walaupun demikian modul IPA ini tetap dilakukannya revisi, dikarenakan hasil akhir dari ke tiga validator memberi keputusan bahwa modul IPA sangat valid dengan sedikit revisi. Setelah melakukan perbaikan maka modul IPA dikategorikan sangat valid artinya modul sudah benar, tepat dan sudah sesuai dengan isi, konstruk dan bahasa.

\section{Praktikalitas Modul IPA}

Hasil dari praktikalitas modul IPA kelas IV ini didapatkan dari hasil analisis penilaian angket respon guru. Guru diminta mengisi angket praktikalitas modul IPA berdasarkan petunjuk pengisian. Berdasarkan hasil dari penilaian praktisi oleh guru kelas IV sekolah dasar 221/II Talang Pamesun ibuk Hartini, S.Pd, mendapatkan nilai 95\% persen maka modul IPA dikategorikan sangat praktis.

Agustyaningrum \& Gusmania (2017) menjelaskan tentang praktikalitas merupakan tingkat keterpakaian atau kemudahan bahan ajar untuk digunakan oleh peserta didik. Aspek praktikalitas yang diukur adalah aspek kemudahan penggunaan dan aspek penyajian. Untuk aspek kemudahan penggunaan meliputi kemudahan memahami materi dan bahasa yang digunakan dalam modul. Sedangkan aspek penyajian fokus pada tampilan modul.

Didapatkan persen nilai sebesar 95\% dengan kriteria sangat baik. Jadi bahan ajar IPA yang dikembangkan oleh peneliti dapat digunakan dalam proses pembelajaran. Dari analisis di atas maka dapat disimpulkan bahwa modul IPA dapat memudahkan siswa dalam proses pembelajaran sesuai dengan harapan dan penilaian.

\section{Efektifitas Modul IPA}

Hasil dari efektifitas modul IPA dapat dilihat dari hasil belajar kelas IV sekolah dasar 221 Talang Pamesun, dengan jumlah orang 14 siswa. Apakah nilai yang diperoleh siswa telah mencapai KKM yang ditentukan. Berdasarkan penelitian yang telah dilakukan, didapatkan persen nilai $78,57 \%$ yang mana terdiri dari 14 orang siswa yang mencapai ketuntasan dan $21,42 \%$ siswa tidak mencapai ketuntasan, maka modul IPA ini dikategorikan sangat efektif.

Wati (2018) menjelaskan tentang efektivitas yaitu efektif yang berarti dapat membuahkan hasil, mulai berlaku, ada pengaruh/akibat/efeknyaEfektivitas adalah suatu ukuran yang menyatakan seberapa jauh target (kuantitas, kualitas dan waktu) telah tercapai. Efektivitas menunjukkan seberapa jauh tercapainya suatu tujuan yang telah ditentukan. Suatu produk (modul) dikatakan efektif apabila adanya pengaruh kepada penggunanya, bisa diartikan sebagai kegiatan yang bisa memberikan hasil belajar yang memuaskan setelah menggunakan modul. Keefektifan modul dapat diketahui dengan menganalisis data tes hasil belajar siswa. Penskoran untuk masing - masing tes belajar di analisis dalam skala 0-100, diharapkan siswa bisa mencapai Kriteria Ketuntasan Minimal (KKM) yang sudah ditetapkan yaitu 70.

Efektivitas modul dilihat berdasarkan pencapaian dari hasil belajar siswa. Hasil belajar diambil selama proses pembelajaran berlangsung menggunakan modul pembelajaran materi gaya dan gerak berbasis model RBL pada keterampilan 4C's siswa. Analisis hasil belajar siswa menunjukkan pencapaian yang baik. Rata-rata nilai siswa yang tuntas adalah $78,57 \%$ sedangkan yang tidak tuntas mendapatkan $21,42 \%$. Pengembangan modul IPA materi gaya dan gerak berbasis model RBL pada keterampilan 4C dapat dikatakan efektif. Jadi hasil akhirnya modul IPA sangat efektif untuk membantu proses belajar siswa di sekolah maupun di rumah. 
4626 Pengembangan Modul IPA SD Berbasis Model Research Based Learning (RBL) untuk Keterampilan 4C's Siswa Sekolah Dasar pada Pembelajaran Tematik - Nina Nurhasanah, Muhammad Subhan, Estuhono DOI: https://doi.org/10.31004/edukatif.v3i6.1530

\section{KESIMPULAN}

Berdasarkan pengembangan yang telah dilakukan terhadap modul IPA pada materi hewan dan tumbuhan, pengumpulan data dan penyajian data kelas IV sekolah dasar 221/II Talang Pamesun Kabupaten Bungo, dapat disimpulkan sebagai berikut: Validitas modul pembelajaran IPA yang dinilai validator yang berjumlah 3 orang, menunjukkan bahwa modul pembelajaran IPA memperoleh persen $81 \%$ dengan kategori sangat valid artinya, modul sudah benar, tepat dan sudah sesuai dengan isi, konstruk dan Bahasa. Praktikalitas yang dinilai dari angket pratikalitas guru terhadap modul pembelajaran IPA yang berjumlah 1 orang guru di sekolah dasar 221/II Talang Pamesun yaitu guru kelas IV memperoleh persen 95\% dengan kategori sangat praktis artinya, modul sudah dapat digunakan dengan mudah untuk proses pembelajaran. Efektifitas yang dinilai dari hasil tes akhir belajar siswa memperoleh $78,57 \%$ dengan kategori sangat efektif artinya modul dapat meningkatkan hasil belajar siswa di SD Negeri 221/II Talang Pamesun.

\section{DAFTAR PUSTAKA}

Agustyaningrum, N., \& Gusmania, Y. (2017). Praktikalitas Dan Keefektifan Modul Geometri Analitik Ruang Berbasis Konstruktivisme. Jurnal Dimensi, 6(3), 412-420. Https://Doi.Org/10.33373/Dms.V6i3.1075

Ainin, M. (2013). Penelitian Pengembangan Dalam Pembelajaran Bahasa Arab. Okara, 2(8), 96.

Anggari, A. St., Afrika, \& Retno, W. D. (2017). Peduli Terhadap Makhluk Hidup.

Apreasta, L. (2019). Pengembangan Bahan Ajar Keterampilan Menulis Narasi Berbasis Guided Writing Di Kelas V Sekolah Dasar.

Apriliana, A., \& Subanti, S. (2015). Eksperimentasi Model Pembelajaran Resource Based Learning ( Rbl) Dan Problem Based Learning ( $\mathrm{Pbl}$ ) Ditinjau Dari Kemam Puan Komunikasi Matematik Peserta Didik Kelas Xi Sma Sekabupaten Kudus Tahun 2013 / 2014. 3(5), 483-494.

Budiono, E., \& Hadi, S. (2006). Penyusunan Dan Penggunaan Modul Pembelajaran Berdasar Kurikulum Berbasis Kompetensi Sub Pokok Bahasan Analisa Kuantitatif Untuk Soal-Soal Dinamika Sederhana Pada Kelas X Semester 1 Sma. Jurnal Pendidikan, 4(4), 1-87. Https://Doi.Org/10.1139/Y72-052

Candra, Tjoeng Surya, \& Indriyani, R. (2014). Surya Candra Tjoeng Dan Ratih Indriyani. Jurnal Manajemen Bisnis, 2(1).

Estuhono. (2020). Efektifitas Pengembangan Perangkat Pembelajaran IPA Berbasis Model Problem Based Instruction Terintegrasi Pendidikan Karakter Untuk Siswa Sekolah Dasar. 5(2), 202-209.

Estuhono, Festiyed, \& Bentri, A. (2019). Preliminary Research Of Developing A Research-Based Learning Model Integrated By Scientific Approach On Physics Learning In Senior High School. Journal Of Physics: Conference Series, 1185(1). Https://Doi.Org/10.1088/1742-6596/1185/1/012041

Fatimah. (2014). Meningkatkan Hasil Belajar Siswa Dalam Pembelajaran IPA Dengan Metode Demonstrasi Dikelas V SDN 10 Biau. Jurnal Kreatif Tadulako Online, 1(4), 164-172. Http://Jurnal.Untad.Ac.Id/Jurnal/Index.Php/JKTO/Article/View/2742

Harisman, Y. (2016). Validitas Dan Praktikalitas Modul Untuk Materi Fungsi Pembangkit Pada Perkuliahan Matematika Diskrit Di Stkip Pgri Sumatera Barat. Admathedu: Jurnal Ilmiah Pendidikan Matematika, Ilmu Matematika Dan Matematika Terapan, 4(2). Https://Doi.Org/10.12928/Admathedu.V4i2.4801

Harta, I., Tenggara, S., \& Kartasura, P. (2014). Pengembangan Modul Pembelajaran Untuk Meningkatkan Pemahaman Konsep Dan Minat SMP. Pengembangan Modul Pembelajaran Untuk Meningkatkan Pemahaman Konsep Dan Minat SMP, 9(2), 161-174. Https://Doi.Org/10.21831/Pg.V9i2.9077

Khaeriyah, E., Warsiti, \& Chrysti, S. K. (2019). Penerapan Model Resource Based Learning (Rbl) Dengan Pendekatan Scientific Dalam Peningkatan Pembelajaran Ipa Di Kelas IV SDN 1 Klapasawit Tahun Ajaran 2014/2015. Concept And Communicati, 3(23), 301-316. 
4627 Pengembangan Modul IPA SD Berbasis Model Research Based Learning (RBL) untuk Keterampilan 4C's Siswa Sekolah Dasar pada Pembelajaran Tematik - Nina Nurhasanah, Muhammad Subhan, Estuhono DOI: https://doi.org/10.31004/edukatif.v3i6.1530

Https://Doi.Org/10.15797/Concom.2019..23.009

Laili, I., Ganefri, \& Usmeldi. (2019). Efektivitas Pengembangan E-Modul Project Based Learning Pada Mata Pelajaran Instalasi. Jurnal Imiah Pendidikan Dan Pembelajaran, 3, 306-315. Https://Ejournal.Undiksha.Ac.Id/Index.Php/JIPP/Article/Download/21840/13513

Matondang, Zulkifli. (2009). Validitas Dan Reliabilitas Suatu Instrumen Penelitian. Jurnal Tabularasa Pps Unimed, 6(1), 1510-1515. Https://Doi.Org/10.4028/Www.Scientific.Net/AMM.496-500.1510

Meilani, D., Dantes, N., \& Tika, I. N. (2020). Pengaruh Implementasi Pembelajaran Saintifik Berbasis Keterampilan Belajar Dan Berinovasi 4C Terhadap Hasil Belajar IPA Dengan Kovariabel Sikap Ilmiah Pada Peserta Didik Kelas V SD Gugus 15 Kecamatan Buleleng. Jurnal Elementary: Kajian Teori Dan Hasil Penelitian Pendidikan Sekolah Dasar, 3(1), 1-5.

Muhammad Wahyu Setiyadi, Ismail, H. A. G. (2017). Pengembangan Modul Pembelajaran Biologi Berbasis Pendekatan Saintifik Untuk Meningkatkan Hasil Belajar Siswa. Journal Of Educational Science And Technology (EST), 3(2), 104.

Purnama, S. (2013). Produk Pembelajaran Bahasa Arab. Literasi, 4(1), 19-32.

Rahayu, P., Mulyani, S., \& Miswadi, S. S. (2012). Jurnal Pendidikan IPA Indonesia Melalui Lesson Study. Jurnal Pendidikan IPA Indonesia, 1(1), 63-70.

Sanjayanti, A. H., Darmayanti, N. W. S., \& ... (2020). Integrasi Keterampilan 4C Dalam Modul Metodologi $\begin{array}{lllll}\text { Penelitian. Jurnal Pedagogi } & \text {.., } & 3(3), & 407-415\end{array}$ Https://Ejournal.Undiksha.Ac.Id/Index.Php/JP2/Article/View/28927

Septikasari, R., \& Frasandy, R. N. (2018). Keterampilan 4C Abad 21 Dalam Pembelajaran Pendidikan Dasar. Tarbiyah Al-Awlad, VIII, 112-122.

Sri Ira Suharwati, Sumarmi, I. N. R. (2016). Pengaruh Model Pembelajaran Resource Based Learning Terhadap Minat Dan Hasil Belajar Geografi Siswa Sma. Jurnal Pendidikan: Teori, Penelitian, Dan Pengembangan, 1(2502-471X), 74-79. Https://Media.Neliti.Com/Media/Publications/211315-PengaruhModel-Pembelajaran-Resource-Bas.Pdf

Surahman, Paudi, Ritman Ishak, \& Tureni, D. (2017). Meningkatkan Hasil Belajar Siswa Dalam Pembelajaran IPA Pokok Bahasan Makhluk Hidup Dan Proses Kehidupan Melalui Media Gambar Kontekstual Pada Siswa Kelas II SD Alkhairaat Towera. Jurnal Kreatif Tadulako Online, 3 No 4, 91107.

Tursinawati. (2013). Analisis Kemunculan Sikap Ilmiah Siswa Dalam Pelaksanaan Percobaan Pada Pembelajaran IPA Di SDN Kota Banda Aceh. Jurnal Pionir, 1(1), 67-84.

Wati, Asren. (2018). Pengembangan Modul Matematika Berbasis Problem Based Learning (PBL) Pada Materi Sistem Persamaan Linier Dua Variabel (SPLDV) Kelas VIII Mts MHD Bunga Tanjung. In Journal Of Materials Processing Technology (Vol. 1, Issue 1). Http://Dx.Doi.Org/10.1016/J.Cirp.2016.06.001\%0Ahttp://Dx.Doi.Org/10.1016/J.Powtec.2016.12.055\%0 Ahttps://Doi.Org/10.1016/J.Ijfatigue.2019.02.006\%0Ahttps://Doi.Org/10.1016/J.Matlet.2019.04.024\%0 Ahttps://Doi.Org/10.1016/J.Matlet.2019.127252\%0Ahttp://Dx.Doi.O 